October 2014 Vol.:2, Issue:3

(C) All rights are reserved by Kaya et al.

\title{
The Effects of Varicocele on DNA Morphology
}

Keywords: Varic ocele; Infertility; Spem DNA damage

\section{Abstract}

Varic ocele is one of the major causes of infertility in men. Although there are different theories related to the pathophysiology of the varic ocele, the exact pathophysiologic mechanism rema ins unknown. Sperm DNA damage may be the cause of undiagnosed infertility problems. The standard semen examination may not be sufficient to determine the etiology of infertility. For this reason, extra tests a re needed to identify sperm DNA damage. Despite conflicting reports, many studies have shown that varic ocele repair improves the quality of sperm DNA.

\section{Varicocele and Infertility}

Infertility is defined as a failure to achieve pregnancy in spite of regular unprotected sex. The male infertility by $50 \%$ contributes to this important health problem affecting about $15-20 \%$ of couples in society $[1,2]$. A study carried out by the World Health Organization (WHO) in1992, which included 9,034 infertile couples, indicated varicocele in $25.4 \%$ of men with disordered sperm parameters and in $11.7 \%$ of men with normal sperm parameters [3]. Varicocele is the dilatation of the pampiniform plexus veins within the spermatic cord [4]. Varicocele occurs in roughly $15 \%$ of the adult male population. The rate of occurrence increases to $21-41 \%$ in men with primary infertility and to approximately $80 \%$ in those with secondary infertility $[5,6]$. Varicocele is found on the left side of the scrotum in $75-95 \%$ of cases. While its bilateral likelihood is $10 \%$, the likelihood of varicocele occurring on the right side of the scrotum is $2 \%[7,8]$.

\section{Etiology and Pathophysiology}

Although there are different theories related to the disease pathophysiology, the effects of varicocele on testicular dysfunction and infertility are not completely understood. However, many pathophysiological mechanisms related to this status have been described. These mechanisms include increased scrotal and intra testicular temperature $[9,10]$, hypoxia [11], low back of adrenal and renal toxic metabolites [12], increased venous pressure [13], immunologic factors [14], apoptosis [15], and impairment of enzymatic functions [16]. Many factors related to varicocele and their risk statuses are shown in Table 1.

Among these mechanisms is the most extensively studied and accepted mechanism of increased testicular heat [17]. In previous studies, the increased heat was shown to decrease the levels of heatshock proteins by affecting androgen synthesis [18]. Researchers demonstrated that increased heat caused by varicocele resulted in disrupted semen parameters and reduced testis tissue-specific heatshock protein (HSPA2) expression when compared to the fertile group. Removal of this issue by varicocelectomy has been shown to ameliorate semen parameters and enhance HSPA2 expression [19]. In addition, the heat increase caused by varicocele affects spermatogenesis by reducing DNA polymerase activity [20].

\section{Journal of}

Andrology \& Gynaecology

\author{
Ozkan Bagci ${ }^{1}$, Ali Murat Gokce ${ }^{2}$, Mustafa Gunes ${ }^{3}$ \\ and Cevdet $\mathrm{Kaya}^{4 *}$ \\ ${ }^{1}$ Department of Medical Genetics, Suleyman Demirel University, \\ School of Medicine, Isparta, Turkey \\ ${ }^{2}$ Haydarpasa Numune Training and Research Hospital, Urology \\ Clinics, Istanbul, Turkey \\ ${ }^{3}$ Department of Urology, Suleyman Demirel University, School of \\ Medicine, Isparta, Turkey \\ ${ }^{4}$ Department of Urology, Marmara University, Medical Faculty, \\ Istanbul, Turkey
}

\section{*Address for Correspondence}

Dr. Cevdet Kaya, MD., Department of Urology, Marmara University, Medical Faculty, Istanbul, Turkey; Tel: +90 021648135 35; E-mail : drckaya@hotmail.com

Submission: 10 July 2014

Accepted: 01 October 2014

Published: 03 October 2014

Table 1: Risk factors related to varicocele.

\begin{tabular}{|c|c|}
\hline Risk factors & Risk status \\
\hline Testicular temperature & increased heat \\
\hline Hypoxia & increased \\
\hline Oxidative stress & increased \\
\hline Tissue-specific heat- shock proteins & decreased levels of expression \\
\hline DNA damage & increased \\
\hline Ychromosome microdeletion & increased \\
\hline Venous pressure & increased \\
\hline Antioxidant capacity & decreased \\
\hline
\end{tabular}

Another mechanism related to the association between varicoceles and male infertility is increased oxidative stress (OS) $[21,22]$. Varicoceles may increase reactive oxygen species (ROS) production and decrease antioxidant capacity. Thus, varicoceles can cause OS [23-25]. A number of studies have demonstrated an increase of OS in serum, semen, and testicular tissues of patients with a clinical diagnosis of varicocele. This suggests that the impairment of sperm parameters found in men with varicocele may be related to oxidative stress [26-31]. Furthermore, OS may cause mtDNA deletions in human spermatozoa and mtDNA mutations can cause impairment of sperm functions [32]. In addition, an abnormal amount of ROS and antioxidants is connected to sperm motility defects and sperm quality $[33,34]$.

Other pathologies that could affect the spermatogenesis in patients with varicocele are $\mathrm{Y}$ chromosome micro deletions, acrosome reaction disorders, protamine deficiency, and endocrinological changes. Whereas $Y$ chromosome micro deletions are found in $0.3-7 \%$ of infertile men, the rate goes up to approximately $18 \%$ in varicocele cases with poor semen parameters and testicular hypotrophy $[35,36]$. Previous studies have suggested that the varicocele may disrupt the acrosome reaction occurring between sperm and the zona pellucida 
[37]. Throughout standard spermiogenesis, $85 \%$ of histones are supplanted with protamines, which causes the sperm chromatin condensation that is necessary for conserving paternal genes and facilitating fertilization $[38,39]$. Several studies have shown a defect in the histone/protamine exchange in patients with varicocele $[38,40]$. Studies investigating the relationship between varicocele and hormonal dysfunction have reported that varicocele decreases the levels of total testosterone and significantly increases hormone levels after varicocelectomy [41].

\section{Varicocele and DNA damage}

In recent years, another mechanism that has been the focus of studies investigating the relationship between varicocele and spermatogenesis is sperm DNA damage. Many studies have demonstrated that sperm DNA damage is detected in a high percentage of infertile males and that treatment provided significant improvement in levels [42-44].

The nucleus of the sperm gets condensed throughout the last phases of spermatogenesis. Thus, sperm DNA becomes more resistant to agents that are damaged. Varicocele may influence the last phases of spermatogenesis and lead to impairments in sperm parameters [45-47]. It is likely that this situation is one of the reasons for unexplained infertility. Sperm DNA damage in particular may be the cause of undiagnosed infertility problems [48]. The standard semen examination may not be sufficient to determine the etiology of infertility. For this reason, extra tests are needed to identify sperm DNA damage.

A recently published meta-analysis showed that patients with varicoceles had significantly higher sperm DNA damage than controls [49]. The sperm DNA fragmentation index (DFI: percentage of sperm with denatured nuclei) contains single and/or double-stranded DNA breaks, which may affect the infertility [50,51]. Researchers proposed that sperm nuclear DNA fragmentation happens even when there are no alterations in sperm quality (as evaluated by routine seminal analysis). Therefore, finding classic sperm parameters does not ensure the absence of DNA damage in the sperm of varicocele patients [52,53]. DNA damage can be caused by intra- or extratesticular factors. The main intra-testicular factors are decreased levels of DNA polymerases, abnormalities in chromatin packing, abortive apoptosis, micro deletions of chromosomal rearrangements, and increased oxidative stress. External factors that cause DNA damage are age, hormonal component, drugs, cigarette smoking, and testicular hyperthermia [39,54-57]. Among these factors, apoptosis and oxidative stress are the most researched.

The authors showed that OS influences the integrity of the sperm chromatin and induces both single-strand and double-strand DNA breaks [58,47]. Moreover, abnormal amounts of ROS cause oxidative stress and impair spermatozoa DNA at both the nuclear and mitochondrial levels [59]. Polyunsaturated fatty acids in the plasma membrane of sperm cells are highly susceptible to damage by ROS. In this process, ROS causes lipid peroxidation and biomembrane damage and can impair DNA by causing deletions and mutations $[60,61]$. In addition, authors have been reported in relationship with an increased ROS and total antioxidant capacity both in infertile patients and those with varicocele [62].
Animal studies have stated that apoptosis is an important regulator of spermatogenesis in normal and pathological situations $[63,64]$. Miura et al. showed that the expression of Fas proteins plays an important role in the apoptosis process increase during an acute heat situation of murine testes [65]. Researchers inferred that the FasL mRNA levels of patients with varicocele were higher than in the control group. They also introduce an adverse connection between sperm concentration and FasL mRNA levels [66]. In addition, Wu et al. assessed apoptosis markers in varicocele patients and they found that nuclear DNA damage and externalization of phosphatidylserine (which plays a key role in the apoptosis process) are increased in varicocele patients [67].

Although many studies to be conducted, the adverse effect of DNA fragmentation on fertilization and pregnancy rates is still a controversial issue. There are various reasons for this, such as the application of several techniques for identifying DNA fragmentation and being of individuals with different sperm characteristics [68-70].

\section{Varicocele and Treatment}

Varicoceles can be corrected with surgical methods such as microscopic varicocelectomy [71]. Many studies have shown that multiple semen parameters, sperm DNA quality, and pregnancy rates improve after a varicocelectomy [72-74]. Moreover, Chen et al. have reported that varicocele repair decreases ROS levels. Therefore, varicocelectomies may repair spermatogenesis and decrease DNA damage due to reduced ROS levels [63]. In addition, Esteves et al. reported that varicocelectomies improve clinical pregnancy and live birth rates by intra cytoplasmic sperm injection. Researchers have shown that varicocelectomies increase the total number of motile sperm and decrease the sperm defect score [75]. Jiang et al. reported that DNA fragmentation index values were significantly correlated to the outcome of intracytoplasmic sperm injection [76]. These facts demonstrate that a varicocelectomy can improve not only the quantity but also the quality of sperm. However, several studies have shown no improvement in semen quality after varicocele repair [77]. These differences in results may be due to the use of different approaches for semen testing and the heterogeneity of patient groups, which includes clinical diversity, individual genetic background, duration of varicocele, and the socioeconomic status of patients [5]. In conclusion, varicocele is an important problem affecting infertility in men. According to the literature, varicocele repair can correct the many pathologies of varicocele.

\section{References}

1. Poongathai J, Gopenath TS, Mononayaki S (2009) Genetics of human male infertility. Singapore Med J 50: 336-347.

2. Jose-Miller AB, Boyden JW, Frey KA (2007) Infertility. Am Fam Physician 75: 849-856.

3. World Health Organization (1992) The influence of varicocele on parameters of infertility in a large group of men presenting to infertility clinic. Fertil Steril 57:1289-1293.

4. Saypol DC (1981) Varicocele. J Androl 2: 61-71.

5. Baazeem A, Belzile E, Ciampi A, Dohle G, Jarvi K, et al. (2011) Varicocele and male factor infertility treatment: a new meta-analysis and review of the role of varicocele repair. Eur Urol 60: 796-808

6. Younglai EV, Collins JA, Foster WG (1998) Canadian semen quality: an 
analysis of sperm density among eleven academic fertility centers. Fertil Steril 70: 76-80.

7. Gat Y, Bachar GN, Zukerman Z, Belenky A, Gornish M (2004) Varicocele: a bilateral disease. Fertil Steril 81: 424-429.

8. Kohler FP (1967) On the etiology of varicocele. J Urol 97: 741-742.

9. Benoff S, Hurley IR, Barcia M, Mandel FS, Cooper GW, et al. (1997) A potential role for cadmium in the etiology of varicocele associated infertility. Fertil Steril 67: 336-347.

10. Saypol DC, Howards SS, Turner TT, Miller ED Jr (1981) Influence of surgically induced varicocele on testicular blood flow, temperature, and histology in adult rats and dogs. J Clin Invest 68: 39-45.

11. Brown JS, Dubin L, Hotchkiss RS (1967) The varicocele as related to fertility. Fertil Steril 18: 46-56.

12. Mac Leod J (1965) Seminal cytology in the presence of varicocele. Fertil Steril 16: 735-757.

13. Shafik A, Bedeir GA (1980) Venous tension patterns in cord veins. In norma and varicocele individuals. J Urol 123: 383-385.

14. Knudson G, Ross L, Stuhldreher D, Houlihan D, Bruns E, et al. (1994) Prevalence of sperm bound antibodies in infertile men with varicocele: the effect of varicocele ligation on antibody levels and semen response. J Urol 151: $1260-1262$

15. Baccelti B, Collodel G, Piomboni P (1996) Apoptosis in human ejaculated sperm cells (notulae semino-logicae-9). J Submicrosc Cytol Pathol 28: $587-$ 596.

16. Fujisawa M, Yoshida S, Matsumoto O, Kojima K, Kamidono S (1988) Decrease of topoisomerase 1 activity in the testes of infertile men with varicocele. Arch Androl 21: 45-50.

17. Mieusset R, Bujan L, Mondinat C, Mansat A, Pontonnier F, et al. (1987) Association of scrotal hyperthermia with impaired spermatogenesis in infertile men. Fertil Steril 48: 1006-1011.

18. Wang C, Cui YG, Wang XH, Jia Y, Sinha Hikim A, et al. (2007) Transient scrotal hyperthermia and levonorgestrel enhance testosterone-induced spermatogenesis suppression in men through increased germ cell apoptosis. J Clin Endocrinol Metab 92: 3292-3304.

19. Nasr Esfahani MH, Tavalaee M (2012) Origin and role of DNA damage in varicocele. Int J Fertil Steril 6: 141-146.

20. Fujisawa M, Yoshida S, Kojima K, Kamidono S (1989) Biochemical changes in testicular varicocele. Arch Androl 22:149-159.

21. A Agarwal, A Hamada, SC Esteves (2012) Insight into oxidative stress in varicocele-associated male infertility: part 1. Nat Rev Urol 9: 678-690.

22. A Zini, G Dohle (2011) Are varicoceles associated with increased deoxyribonucleic acid fragmentation?. Fertil Steril 96: 1283-1287.

23. Hendin B, Kolettis P, Sharma RK, Thomas AJ Jr, Agarwal A (1999) Varicocele is associated with elevated spermatozoal reactive oxygen species production and diminished seminal plasma antioxidant capacity. J Urol 161: 1831-1834.

24. Simsek F, Turkeri L, Cevik I, Bircan K, Akdas A (1998) Role of apoptosis in testicular tissue damage caused by varicocele. Arch Esp Urol 51: 947-950.

25. Allamaneni SS, Naughton CK, Sharma RK, Thomas AJ, Agarwal A (2004) Increased seminal reactive oxygen species levels in patients with varicoceles correlate with varicocele grade but not with testis size. Fertil Steril 82:16841686.

26. French DB, Desai NR, Agarwal A (2008) Varicocele repair: does it still have a role in infertility treatment? Curr Opin Obstet Gynecol 20: 269-274.

27. Barbieri ER, Hidalgo ME, Venegas A, Smith R, Lissi EA (1999) Varicocele associated decrease in antioxidant defenses. J Androl 20:713-717.

28. Hendin BN, Kolettis PN, Sharma RK, Thomas AJ Jr, Agarwal A (1999) Varicocele is associated with elevated spermatozoal reactive oxygen species production and diminished seminal plasma antioxidant capacity. J Urol 161:1831-1834.
29. Pasqualotto FF, Sharma RK, Nelson DR, Thomas AJ, Agarwal A (2000) Relationship between oxidative stress, semen characteristics, and clinical diagnosis in men undergoing infertility investigation. Fertil Steril 73: 459-464.

30. Zini A, Defreitas G, Freeman M, Hechter S, Jarvi K (2000) Varicocele is associated with abnormal retention of cytoplasmic droplets by human spermatozoa. Fertil Steril 74:461-464

31. Meucci E, Milardi D, Mordente A, Martorana GE, Giacchi E, et al. (2003) Total antioxidant capacity in patients with varicoceles. Fertil Steril 79: 1577-1583.

32. Shamsi MB, Kumar R, Bhatt A, Bamezai RN, Kumar R, et al. (2008) Mitochondrial DNA mutations in etiopathogenesis of male infertility. Indian J Urol 24: 150-154.

33. Gil-Guzman E, Ollero M, Lopez MC, Sharma RK, Alvarez JG, et al. (2001) Differential production of reactive oxygen species by subsets of human spermatozoa at different stages of maturation. Hum Reprod 16: 1922-1930.

34. Hammadeh ME, Filippos AA, Hamad MF (2009) Reactive oxygen species and antioxidant in seminal plasma and their impact on male fertility. Int J Fertil Steril 3: 87-110.

35. Maurer B, Gromoll J, Simoni M, Nieschlag E (2001) Prevalence of Y chromosome microdeletions in infertile men who consulted a tertiary care medical centre: the Munster experience. Andrologia 33: 27-33.

36. Pryor JL, Kent-First M, Muallem A, Van Bergen AH, Nolten WE, Meisner L, et al. (1997) Microdeletions in the $Y$ chromosome of infertile men. N Engl J Med 336: 534- 539.

37. Benoff S, Hurley I, Cooper GW, Mandel FS, Rosenfeld DL, et al. (1993) Head-specific mannose-ligand receptor expression in human spermatozoa is dependent on capacitation-associated membrane cholesterol loss. Hum Reprod 8:2141-2154.

38. Oliva R (2006) Protamines and male infertility. Hum Reprod Update 12: 417 435.

39. Zini A, Libman J (2006) Sperm DNA damage: clinical significance in the era of assisted reproduction. CMAJ 175: 495-500.

40. El-Segini Y, Schill WB, Köhn FM, Zeid SA, Kamshushy AA, et al. (2002) Assessment of sperm functions in infertile patients with varicoceles. Andrologia 34: 291-295.

41. Hudson RW, Perez-Marrero RA, Crawford VA, McKay DE (1985) Hormonal parameters of men with varicoceles before and after varicocelectomy. Fertil Steril 43: 905-910.

42. Zini A Blumenfeld A, Libman J, Willis J (2005) Beneficial effect of microsurgical varicocelectomy on human sperm DNA integrity.; Hum Reprod 20: 1018-1021.

43. Spanò M, Bonde JP, Hjøllund HI, Kolstad HA, Cordelli E, et al. (2000) Sperm chromatin damage impairs human fertility. The Danish First Pregnancy Planner Study Team. Fertil Steril 73: 43-50.

44. Bungum M, Humaidan P, Spano M, Jepson K, Bungum L, et al. (2004) The predictive value of sperm chromatin structure assay (SCSA) parameters for the outcome of intrauterine insemination, IVF and ICSI. Hum Reprod 19: 1401-1408.

45. Barratt CL, Aitken RJ, Bjorndahl L, Carrell DT, de Boer P, et al. (1010) Sperm DNA: organization, protection and vulnerability: from basic science to clinical applications--a position report. Hum Reprod 25: 824-838.

46. Fuse H, Akashi T, Mizuno I, Nozaki T, Watanabe A (2006) Postoperative changes of sperm chromatin heterogeneity, using acridine orange staining, in varicocele patients. Arch Androl 52: 223-226.

47. Saleh RA, Agarwal A, Sharma RK, Said TM, Sikka SC, et al. (2003) Evaluation of nuclear DNA damage in spermatozoa from infertile men with varicocele. Fertil Steril 80: 1431-1436.

48. Gopalkrishnan K, Hurkadli K, Padwal V, Balaiah D (1999) Use of acridine orange to evaluate chromatin integrity of human spermatozoa in different groups of infertile men. Andrologia 31: 277-282.

49. YJ Wang, RQ Zhang, YJ Lin, RG Zhang, WL Zhang (2012) Relationship 
between varicocele and sperm DNA damage and the effect of varicocele repair: a meta-analysis, Reprod BioMed Online 25: 307-314.

50. Muratori M, Piomboni $\mathrm{P}$, Baldi E, Filimberti E, Pecchioli $\mathrm{P}$, et al. (2000) Functional and ultra structural features of DNA fragmented human sperm. JAndrol 21: 903-912.

51. Razavi SH, Nasr-Esfahani MH, Mardani M (2006) The role of sperm chromatin anomalies on the outcome of assisted reproductive techniques. Yakhteh 7 : 206-215

52. Bertolla RP1, Cedenho AP, Hassun Filho PA, Lima SB, Ortiz V, et al. (2006) Sperm nuclear DNA fragmentation in adolescents with varicocele, Fertil Steril 85: 625-628

53. R Smith, H Kaune, D Parodi, M Madariaga, R Rios (2006) Increased sperm DNA damage in patients with varicocele: relationship with seminal oxidative stress, Hum Reprod 21: 986-993.

54. Moustafa MH1, Sharma RK, Thornton J, Mascha E, Abdel-Hafez MA et al. (2004) Relationship between ROS production, apoptosis and DNA denaturation in spermatozoa from patients examined for infertility. Hum Reprod 19: 129-138.

55. Sakkas D, Mariethoz E, Manicardi G, Bizzaro D, Bianchi PG, et al. (1999) Origin of DNA damage in ejaculated human spermatozoa. Rev Reprod 4 31-37.

56. Cho C, Willis WD, Goulding EH, Jung-Ha H, Choi YC, et al. (2001) Haplo insufficiency of protamine-1 or -2 causes infertility in mice. Nat Genet 28: 82 86.

57. Fujisawa M, Yoshida S, Matsumoto O, Kojima K, Kamidono S (1988) Deoxyribonucleic acid polymerase activity in the testes of infertile men with varicocele. Fertil Steril 50: 795-800.

58. Aitken RJ, Krausz C (2001) Oxidative stress, DNA damage and the $Y$ chromosome. Reproduction 122: 497-506.

59. NG Gashti, Z Salehi , AH Madani , ST Dalivandan (2013) 4977-bp mitochondrial DNA deletion in infertile patients with varicocele, Andrologia 46: $258-262$.

60. Agarwal A, Prabakaran SA, Said TM (2005) Prevention of oxidative stress injury to sperm. J Androl 26: 654-660.

61. Chen SS, Huang WJ, Chang LS, Wei YH (2008) Attenuation of oxidative stress after varicocelectomy in subfertile patients with varicocele. J Urol 179 639-642.

62. Abd-Elmoaty MA, Saleh R, Sharma R, Agarwal A (2010) Increased levels of oxidants and reduced antioxidants in semen of infertile men with varicocele. Fertil Steril 94: 1531-1534.

63. Rodriguez I, Ody C, Araki K, Garcia I, Vassalli P (1997) An early and massive wave of germinal cell apoptosis is required for the development of functional spermatogenesis. EMBO J 16: 2262-2270.

64. Lin WW, Lamb DJ, Lipshultz LI and Kim ED (1999) The role of autosomal cell apoptosis regulator genes in human spermatogenesis. Int Urol Nephrol 31: 237-246.

65. Miura M, Sasagawa I, Suzuki Y, Nakada T, Fujii J (2002) Apoptosis and expression of apoptosis-related genes in the mouse testis following heat exposure. Fertil Steril 77: 787-793

66. Del Giudice PT, Lima SB, Cenedeze MA, Pacheco Silva A, Bertolla RP, et al. (2010) Expression of the Fas-ligand gene in ejaculated sperm from adolescents with and without varicocele. J Assist Reprod Genet 27: 103-109.

67. Wu GJ, Chang FW, Lee SS, Cheng YY, Chen CH (2009) Apoptosis-related phenotype of ejaculated spermatozoa in patients with varicocele. Fertil Steril 91: 831-837.

68. O'Brien J, Zini A (2005) Sperm DNA integrity and male infertility. Urology 65 16-22.

69. Tarozzi N, Bizzaro D, Flamigni C, Borini A (2007) Clinical relevance of sperm DNA damage in assisted reproduction. Reprod Biomed Online 14:746-757.

70. Makhlouf AA, Niederberger CS, (2006) Ensuring vasectomy success: what is the standard? J Androl 27: 637-640.

71. Cayan S, Lee D, Black LD, Reijo-Pera RA, Turek PJ (2001) Response to varicocelectomy in oligospermic men with and without defined genetic infertility. Urology 57: 530-535.

72. Madgar I, Weissenberg R, Lunenfeld B, Karasik A, Goldwasser B (1995) Controlled trial of high spermatic vein ligation for varicocele in infertile men. Fertil Steril 63:120-124.

73. Li F, Yamaguchi K, Okada K, Matsushita K, Ando M, et al. (2012) Significant improvement of sperm DNA quality after microsurgical repair of varicocele. Syst Biol Reprod Med 58: 274-247.

74. Daitch JA1, Bedaiwy MA, Pasqualotto EB, Hendin BN, Hallak J, et al. (2001) Varicocelectomy improves intrauterine insemination success rates among men with varicocele. J Urol 165: 1510-1513.

75. SC Esteves, FV Oliveira, RP Bertolla (2010) Clinical Outcome of Intracytoplasmic Sperm Injection in Infertile Men With Treated and Untreated Clinical Varicocele. J urol 184: 1442-1446.

76. Jiang H, He RB, Wang CL, Zhu J (2011) The relationship of sperm DNA fragmentation index with the outcomes of in-vitro fertilisation-embryo transfer and intracytoplasmic sperm injection. J Obstet Gynaecol 31: 636-639.

77. Gerhard I, Lenhard K, Eggert-Kruse W, Runnebaum B (1992) Clinical data which influence semen parameters in infertile men. Hum Reprod 7: 830-837. 